\title{
Front Matter: Volume 9336
}

, "Front Matter: Volume 9336," Proc. SPIE 9336, Quantitative Phase Imaging, 933601 (20 April 2015); doi: 10.1117/12.2192892

SPIE. Event: SPIE BiOS, 2015, San Francisco, California, United States 


\section{PROGRESS IN BIOMEDICAL OPTICS AND IMAGING}

Vol. 16 No. 34

\section{Quantitative Phase Imaging}

Gabriel Popescu

YongKeun Park

Editors

7-10 February 2015

San Francisco, California, United States

Sponsored and Published by

SPIE

Volume 9336 
The papers included in this volume were part of the technical conference cited on the cover and title page. Papers were selected and subject to review by the editors and conference program committee. Some conference presentations may not be available for publication. The papers published in these proceedings reflect the work and thoughts of the authors and are published herein as submitted. The publisher is not responsible for the validity of the information or for any outcomes resulting from reliance thereon.

Please use the following format to cite material from this book:

Author(s), "Title of Paper," in Quantitative Phase Imaging, edited by Gabriel Popescu, YongKeun Park, Proceedings of SPIE Vol. 9336 (SPIE, Bellingham, WA, 2015) Article CID Number.

ISSN: 1605-7422

ISBN: 9781628414264

Published by

SPIE

P.O. Box 10, Bellingham, Washington 98227-0010 USA

Telephone +1 3606763290 (Pacific Time) · Fax +1 3606471445

SPIE.org

Copyright (C) 2015, Society of Photo-Optical Instrumentation Engineers.

Copying of material in this book for internal or personal use, or for the internal or personal use of specific clients, beyond the fair use provisions granted by the U.S. Copyright Law is authorized by SPIE subject to payment of copying fees. The Transactional Reporting Service base fee for this volume is $\$ 18.00$ per article (or portion thereof), which should be paid directly to the Copyright Clearance Center (CCC), 222 Rosewood Drive, Danvers, MA 01923. Payment may also be made electronically through CCC Online at copyright.com. Other copying for republication, resale, advertising or promotion, or any form of systematic or multiple reproduction of any material in this book is prohibited except with permission in writing from the publisher. The CCC fee code is $1605-7422 / 15 / \$ 18.00$.

Printed in the United States of America.

Publication of record for individual papers is online in the SPIE Digital Library.

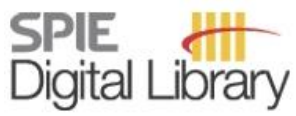

SPIEDigitalLibrary.org

Paper Numbering: Proceedings of SPIE follow an e-First publication model, with papers published first online and then in print. Papers are published as they are submitted and meet publication criteria. A unique citation identifier (CID) number is assigned to each article at the time of the first publication. Utilization of CIDs allows articles to be fully citable as soon as they are published online, and connects the same identifier to all online, print, and electronic versions of the publication. SPIE uses a six-digit CID article numbering system in which:

- The first four digits correspond to the SPIE volume number.

- The last two digits indicate publication order within the volume using a Base 36 numbering

system employing both numerals and letters. These two-number sets start with 00, 01, 02, 03, 04, $05,06,07,08,09,0 A, 0 B \ldots$. 0Z, followed by 10-1Z, 20-2Z, etc.

The CID Number appears on each page of the manuscript. The complete citation is used on the first page, and an abbreviated version on subsequent pages. 


\title{
Contents
}

\author{
vii Authors \\ ix Conference Committee \\ xi Introduction
}

\section{SESSION $1 \quad$ QPI METHODOLOGIES I}

933603 Path-length stabilized low-coherent reflection-type quantitative phase microscope for nanometer-resolution profiling of plasma membrane [9336-2]

933609 Differential fluorescence holography [9336-8]

9336 OA Quantitative phase recovery from asymmetric illumination on an LED array microscope [9336-9]

\section{SESSION 2 QPI METHODOLOGIES II}

9336 OB Multiplexed off-axis interferometric phase microscopy for dynamic cell measurements (Invited Paper) [9336-10]

$93360 \mathrm{C}$ Using electrochemistry: total internal refection imaging ellipsometry to monitor biochemical oxygen demand on the surface tethered polyelectrolyte modified electrode [9336-11]

9336 OE Towards an incoherent off-axis digital holographic microscope [9336-13]

9336 OF Fast control of temporal and spatial coherence properties of microscope illumination using DLP projector [9336-14]

9336 OG Experimental setup combining Digital Holographic Microscopy (DHM) and fluorescence imaging to study gold nanoparticle mediated laser manipulation [9336-15]

9336 OK Coherence-controlled holographic microscopy for live-cell quantitative phase imaging [9336-19]

\section{SESSION 3 QPI METHODOLOGIES III}

$9336 \mathrm{ON}$ Halo-free quantitative phase imaging with partially coherent light [9336-22]

$933600 \quad$ Partially coherent phase imaging with source shapes estimation [9336-23]

9336 OP Quantitative phase-shifting DIC using programmable spatial light modulators [9336-24] 
9336 OS CINCH (Confocal Incoherent Correlation Holography) super resolution fluorescence microscopy based upon FINCH (Fresnel Incoherent Correlation Holography) (Invited Paper) [9336-27]

9336 OT Quantitative phase imaging through scattering media [9336-28]

SESSION 4 QPI ALGORITHMS AND IMAGING PROCESSING

$9336 \mathrm{OW} \quad$ Fast processing of quantitative phase profiles from off-axis interferograms for real-time applications [9336-32]

$9336 \mathrm{OZ} \quad \mathrm{C}++$ software integration for a high-throughput phase imaging platform [9336-35]

933610 Phase correction in low coherence diffraction phase microscopy using the optical transfer function [9336-36]

\section{SESSION $5 \quad$ QPI OF CELLS AND TISSUES I}

933612 Holographic quantitative imaging of sample hidden by turbid medium or occluding objects [9336-38]

933614 Differentiating neutrophils using the optical Coulter counter [9336-40]

933616 Bright-field Quantitative Phase Microscopy (BFQPM) for accurate phase imaging using conventional microscopy hardware [9336-42]

933617 Multimodal label-free growth and morphology characterization of different cell types in a single culture with quantitative digital holographic phase microscopy (Invited Paper) [9336-43]

933619 Prostate cancer diagnosis using quantitative phase imaging and machine learning [9336-45]

\section{SESSION 6 QPI METHODOLOGIES IV}

9336 IF Quantitative phase imaging with programmable illumination [9336-51]

SESSION 7 QPI FOR INDUSTRIAL APPLICATIONS

9336 11 Semiconductor defect metrology using laser-based quantitative phase imaging [9336-53]

$93361 \mathrm{~K}$ In-situ measurements of nanoscale phenomena using diffraction phase microscopy [9336-55] 
$93361 \mathrm{M} \quad$ Label-free measurements of membrane tether thickness using optical tweezers combined with SLIM [9336-56]

$93361 Q \quad$ Nuclear dynamics in metastatic cells studied by quantitative phase imaging [9336-132]

9336 IR Diagnosis of breast cancer biopsies using quantitative phase imaging [9336-61]

$93361 \mathrm{U}$ QPI for prostate cancer diagnosis: quantitative separation of Gleason grades 3 and 4 [9336-64]

9336 IV 3D quantitative phase imaging of neural networks using WDT [9336-65]

SESSION $9 \quad$ QPI OF CELLS AND TISSUES III

$93361 \mathrm{X} \quad$ Using digital inline holographic microscopy and quantitative phase contrast imaging to assess viability of cultured mammalian cells [9336-67]

$93361 \mathrm{Y} \quad$ High throughput imaging of blood smears using white light diffraction phase microscopy [9336-68]

933625 Lab on chip optical imaging of biological sample by quantitative phase microscopy [9336-75]

\section{POSTER SESSION}

933629 Common-path diffraction optical tomography with a low-coherence illumination for reducing speckle noise [9336-81]

9336 2G Method for observing phase objects without halos and directional shadows [9336-88]

9336 2K Quantitative phase imaging of cellular and subcellular structures for non-invasive screening diagnostics of socially significant diseases [9336-92]

9336 2M Multi-mode microscopy in real-time with LED array illumination [9336-94]

$93362 \mathrm{P} \quad$ White-light interferometric microscopy for wafer defect inspection [9336-98] 
Proc. of SPIE Vol. $9336933601-6$

Downloaded From: https://www.spiedigitallibrary.org/conference-proceedings-of-spie on 26 Apr 2023 Terms of Use: https://www.spiedigitallibrary.org/terms-of-use 


\section{Authors}

Numbers in the index correspond to the last two digits of the six-digit citation identifier (CID) article numbering system used in Proceedings of SPIE. The first four digits reflect the volume number. Base 36 numbering is employed for the last two digits and indicates the order of articles within the volume. Numbers start with 00, 01, 02, 03, 04, 05, 06, 07, 08, 09, 0A, 0B...0Z, followed by 10-1Z, 20-2Z, etc.

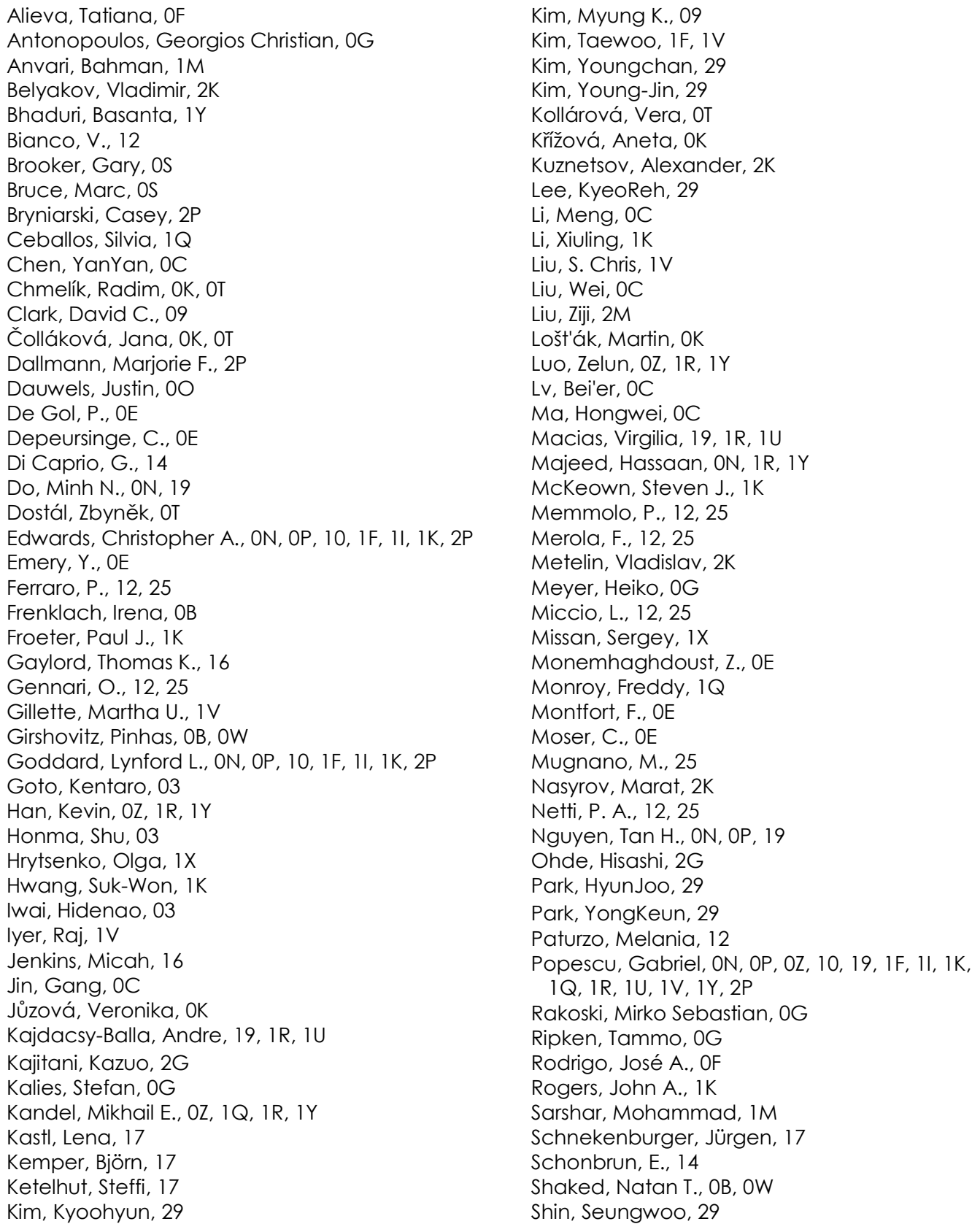


Siegel, Nisan, OS

Slabý, Tomáš, OK, OT

Sridharan, Shamira, 19, 1Q, IU

Steltner, Benjamin, 0G

Storrie, Brian, OS

Sukhenko, Evgeniy, 2K

Suzuki, Yoshimasa, 2G

Tangella, Krishnarao, IR, IU, IY

Tian, Lei, 0A, 0O, 2M

Vasilenko, Irina, $2 \mathrm{~K}$

Veselý, Pavel, OK, OT

Waller, Laura, 0A, 0O, 2M

Wibbeling, Jana, 17

Wong, Winson T., 1M

Yamashita, Yutaka, 03

Yamauchi, Toyohiko, 03

Zhong, Jingshan, 00

Zhou, Renjie, 11, 2P 


\title{
Conference Committee
}

\author{
Symposium Chairs
}

James G. Fujimoto, Massachusetts Institute of Technology

(United States)

R. Rox Anderson, Wellman Center for Photomedicine, Massachusetts General Hospital (United States) and Harvard School of Medicine (United States)

Program Track Chairs

Ammasi Periasamy, University of Virginia (United States)

Daniel L. Farkas, University of Southern California (United States)

Conference Chairs

Gabriel Popescu, University of Illinois at Urbana-Champaign (United States)

YongKeun Park, KAIST (Korea, Republic of)

Conference Program Committee

George Barbastathis, Massachusetts Institute of Technology (United States)

Audrey K. Ellerbee, Stanford University (United States)

Pietro Ferraro, Istituto Nazionale di Ottica (Italy)

Myung K. Kim, University of South Florida (United States)

Theo Lasser, Ecole Polytechnique Fédérale de Lausanne (Switzerland)

Jerome Mertz, Boston University (United States)

Aydogan Ozcan, University of California, Los Angeles (United States)

Demetri Psaltis, Ecole Polytechnique Fédérale de Lausanne (Switzerland)

Colin James Richard Sheppard, Istituto Italiano di Tecnologia (Italy)

Peter T. C. So, Massachusetts Institute of Technology (United States)

Gert von Bally, Westfälische Wilhelms- Universität Münster (Germany)

Laura Waller, University of California, Berkeley (United States)

Changhuei Yang, California Institute of Technology (United States)

\section{Session Chairs}

1 QPI Methodologies I

Gabriel Popescu, University of Illinois at Urbana-Champaign

(United States)

Jerome Mertz, Boston University (United States) 
2 QPI Methodologies ॥

Aydogan Ozcan, University of California, Los Angeles (United States) George Barbastathis, Massachusetts Institute of Technology

(United States)

3 QPI Methodologies III

Björn Kemper, Westfälische Wilhelms-Universität Münster (Germany)

Myung K. Kim, University of South Florida (United States)

4 QPI Algorithms and Imaging Processing

Laura Waller, University of California, Berkeley (United States)

5 QPI of Cells and Tissues I

YongKeun Park, KAIST (Korea, Republic of)

Gabriel Popescu, University of Illinois at Urbana-Champaign

(United States)

6 QPI Methodologies IV

YongKeun Park, KAIST (Korea, Republic of)

7 QPI for Industrial Applications

Pietro Ferraro, Istituto Nazionale di Ottica (Italy)

8 QPI of Cells and Tissues II

Demetri Psaltis, Ecole Polytechnique Fédérale de Lausanne

(Switzerland)

YongKeun Park, KAIST (Korea, Republic of)

9 QPI of Cells and Tissues III

Audrey K. Ellerbee, Stanford University (United States)

Peter T. C. So, Massachusetts Institute of Technology (United States) 


\section{Introduction}

2015, The International Year of Light, marks also, in a fortunate coincidence, the launch of the first conference on Quantitative Phase Imaging (QPI) at Photonics West, BiOS. It was a tremendous success! For four full days, February 7-10, the QPI conference hosted a dense program of oral presentations, covering both novel methodologies and applications to biomedicine. Each presentation was followed by insightful comments, questions, and truly engaging discussions about the state of the art and future directions of the field. Including the poster presentations, the inaugural year of the conference included more than 100 contributions. Clearly, this is a strong message that the QPI field is maturing and that the timing for organizing the conference is right.

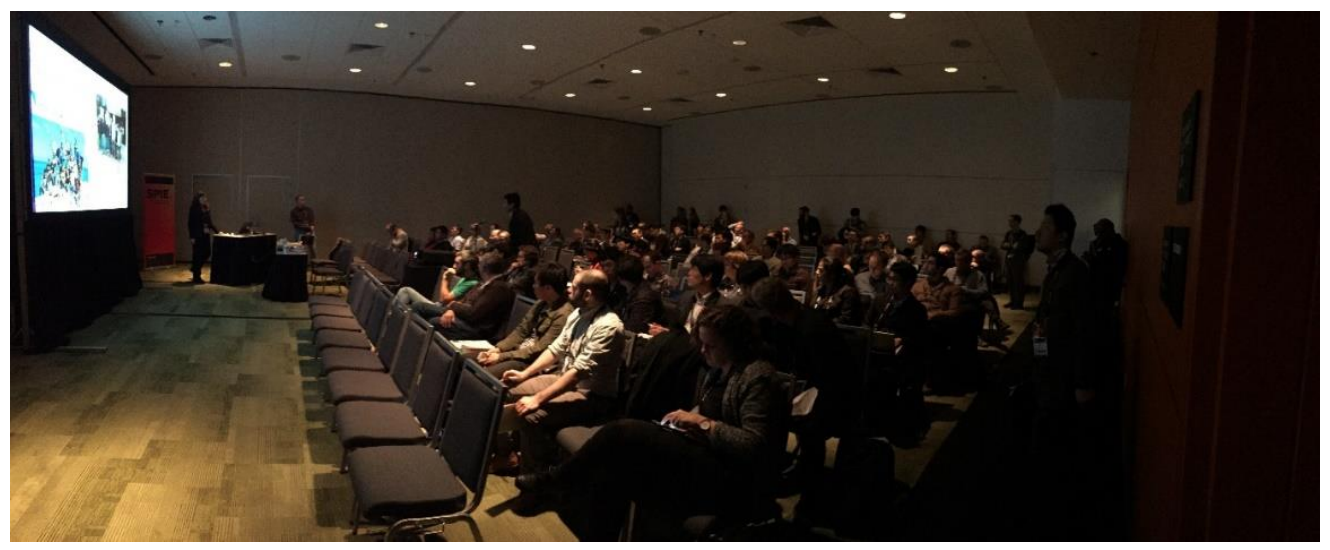

Figure 1. A morning session during the QPI Conference at Photonics West, BiOS (San Francisco, 7-10 Feb. 2015)

QPI is a special type of imaging that allows for quantitative biological investigations. It enables label-free quantitative assessment of biological samples, including cells and tissues. There has been a recent growth in the study of techniques and applications of QPI aimed at addressing important biological questions, previously not possible using conventional optical imaging techniques. This rapidly emerging field enables the investigation of cells and tissues in terms of morphology and dynamics with nanoscale sensitivity over temporal scales from milliseconds to days. Quantitative measurements of intrinsic properties, optical, chemical, and mechanical, are likely to open a new window into the pathophysiology of cells and tissues. Employing the principles of interferometry and holography, QPI provides unique capabilities not only for imaging, but for propagation of optical fields as well. As a result, QPI grants opportunities for non-iterative adaptive optics and for measuring light scattering. Thus, quantitative phase imaging has recently bridged the gap between the imaging and scattering disciplines. 
This is the inaugural proceedings volume on Quantitative Phase Imaging. The papers published in this issue cover the latest developments and applications in one of the most extensive and fast growing fields in biomedical optics. The objective of this volume is to highlight recent progress and trends in novel optical technology developments, as well as their biological, clinical, and industrial applications. The papers published here can be categorized under the following major topics:

1. Imaging

2. Spectroscopy

3. Light scattering measurement

4. Algorithms and Imaging Processing in QPI

5. QPI of cells and tissues.

These topics are discussed in the contributed papers, covering original results and recent developments. Many of the papers published in this special issue represent in-depth elaboration of topics presented at the Quantitative Phase Imaging conference, Photonics West, BiOS, 2015. As Chairs of the QPI conference, we are grateful to the contributors to this volume and all the conference participants who have helped shape this exciting field of quantitative phase imaging.

Gabriel Popescu
YongKeun Park

YongKeun Park 